\title{
UME KBUBU SEBAGAI WUJUD KEARIFAN LOKAL MASYARAKAT BOTI DALAM MENJAGA KETAHANAN PANGAN DAN BENCANA
}

\author{
UME KBUBU AS THE LOCAL WISDOM TO MAINTAIN \\ DISASTER RESILIENCE AND FOOD SECURITY \\ IN THE BOTI COMMUNITY
}

\author{
Iswanto \\ Institut Agama Kristen Negeri (IAKN) Kupang \\ Jln. Naimata (Kampus IAKN Naimata), Kupang-NTT, Indonesia \\ puskom@staknkupang.ac.id
}

Diterima tanggal 24 Agustus 2020

Disetujui tanggal 29 Juni 2021

\begin{abstract}
Local wisdom defined as the ability of a community to adapt to, organize, and manage the environment and culture that affects their lives. The research conducted in the Boti community of East Nusa Tenggara Province aims to describe and understand ume kbubu as a form of local wisdom of the Boti community in maintaining food security and protecting them from disasters. The method used in this study was a qualitative method with a phenomenological approach. The characteristics of this research data are classified as sensitive research data; therefore, it takes a long time to obtain. Observation and interviews were data collection techniques used in this research. The result indicated that the structure of ume kbubu shows the local wisdom of the Boti community in adapting to the environment and influencing the scattered settlement structures. In addition, the function and symbolization of ume kbubu are closely related to the local wisdom of the community in storing and managing staple food (corn), which is the strength of the Boti community in facing the food crisis. The settlement structure of the Boti community, supported by strict customary rules, becomes a barrier in social interaction that can protect the community from disasters, such as infectious diseases. The local wisdom of the Boti community is likely to be an input for the government to study various cultural aspects to deal with disasters.
\end{abstract}

Keywords: local wisdom, ume kbubu, Boti, food security, and disaster resilience.

\begin{abstract}
ABSTRAK
Kearifan lokal dapat diartikan sebagai kemampuan suatu masyarakat untuk beradaptasi, mengatur, serta mengolah lingkungan alam dan budaya yang memengaruhi kehidupan mereka. Penelitian yang dilakukan pada masyarakat Boti di Provinsi Nusa Tenggara Timur ini bertujuan untuk mendeskripsikan dan memahami ume kbubu sebagai wujud kearifan lokal masyarakat Boti dalam menjaga ketahanan pangan dan melindungi mereka dari bencana.
\end{abstract}


Metode yang digunakan ialah metode kualitatif dengan pendekatan fenomenologi. Karakteristik data penelitian ini tergolong dalam data penelitian sensitif, karenanya membutuhkan waktu yang lama untuk memperolehnya. Teknik pengumpulan data yang digunakan adalah pengamatan dan wawancara. Hasil penelitian menunjukkan bahwa struktur ume kbubu memperlihatkan kearifan lokal masyarakat Boti dalam beradaptasi dengan lingkungan alam dan memengaruhi terbentuknya struktur permukiman masyarakat Boti yang menyebar. Selain itu, fungsi dan simbolisasi ume kbubu berkaitan erat dengan kearifan lokal masyarakat dalam menyimpan dan mengelola bahan makanan (jagung), yang menjadi kekuatan masyarakat Boti dalam menghadapi bencana krisis pangan. Struktur permukiman masyarakat Boti yang ditopang dengan aturan adat yang ketat menjadi pembatas dalam interaksi sosial yang mampu melindungi masyarakat dari bencana, misalnya penyakit menular. Kearifan lokal yang dimiliki masyarakat Boti ini diharapkan dapat menjadi masukan bagi pemerintah untuk mengkaji berbagai aspek budaya yang bermanfaat dalam menghadapi bencana.

Kata kunci: kearifan lokal, ume kbubu, Boti, ketahanan pangan, dan bencana.

\section{A. PENDAHULUAN}

Budaya sebagai sebuah konsep dapat diartikan sebagai kerangka identitas, sebagaimana identitas lokal terbentuk. Setiap komunitas lokal mengekspresikan budaya dan kemampuan mereka untuk bertahan hidup melalui cara-cara unik dalam upaya mereka berinteraksi dengan lingkungan sekitarnya. Pada konsep dan kondisi seperti ini dapat dijumpai makna kearifan lokal.

Kearifan lokal memiliki makna yang luas dalam sudut pandang antropologi. Namun, di antara keluasan makna tersebut, fokus dapat disematkan pada pemaknaan kearifan lokal sebagai suatu kemampuan yang dimiliki oleh masyarakat untuk beradaptasi, mengatur, serta mengolah lingkungan alam dan budaya yang memengaruhi kehidupan mereka. Sudah sejak lama siklus hidup manusia ditata sedemikian rupa dan hal tersebut merupakan kekuatan dalam melestarikan kebudayaan asli. Bukti kearifan lokal dapat ditemukan dalam catatan arkeologi material dari prasejarah dan sejarah awal (Pesurnay 2018:2).

Berkaitan dengan hal tersebut, konsep kearifan lokal dapat dikaitkan dengan sistem komunikasi dalam simbol, peristiwa, dan produk budaya (Carbaugh 2007a:167). Kearifan lokal tidak hanya sebagai sistem adaptif masyarakat, tetapi juga diartikan sebagai kekhasan masyarakat yang terinternalisasikan menjadi suatu pesan kepada dunia luar (Leipold et al. 2019:446). Dalam konteks ini, peristiwa-peristiwa yang terjadi berkaitan satu dengan yang lainnya dalam interaksi tersebut (Iparraguirre 2016:613).

Telah terdapat cukup banyak kajian terdahulu yang menunjukkan adanya berbagai bentuk kearifan lokal dan upaya masyarakat untuk memanfaatkan kearifan lokal tersebut. Studi Indrayuda (2017), misalnya, mengungkapkan kearifan lokal pada tarian Minangkabau yang hingga kini masih bertahan dan ditampilkan dalam 
berbagai peristiwa budaya. Tari-tarian masyarakat Minangkabau tersebut dipresentasikan melalui gerakan, ritme, ekspresi, serta aksesori busana. Menurut Indrayuda, atribut-atribut yang terkandung dalam tari-tarian itu membawa pesan dan nilai yang hidup dan berkembang di masyarakat Minangkabau, yang menunjukkan kearifan lokal mereka (2017:150).

Selanjutnya adalah studi Sari (2019) mengenai kearifan lokal dalam bentuk sastra lisan yang terdapat pada tradisi sinandong Melayu Tanjungbalai. Tradisi ini digunakan pada upacaraupacara perkawinan adat Melayu dan juga berfungsi sebagai hiburan. Nilai kearifan lokal yang terkandung dalam tradisi lisan sinandong Melayu Tanjungbalai yaitu kerja keras, pendidikan, dan kesehatan (Sari 2019:1011).

Bentuk kearifan lokal lain terdapat diwujudkan oleh masyarakat di Desa Selat dalam menjaga hutan, seperti dalam penelitian Christiawan (2017). Masyarakat lokal di Desa Selat, Kabupaten Buleleng, Provinsi Bali merupakan masyarakat yang tinggal di kawasan hutan, yang memiliki kesadaran akan ancaman deforestasi. Mereka berusaha mengendalikan ancaman tersebut dengan menggunakan lanskap budaya berbasis kearifan lokal. Dalam penelitian ini, wujud kearifan lokal yang digunakan untuk pengendalian deforestasi dapat berupa: (1) gagasan dengan awig-awig atau hukum adat; (2) kegiatan yang melibatkan pecalang, yaitu petugas khusus yang menjaga ketertiban pelaksanaan adat istiadat; dan (3) artefak dengan keberadaan kuil di hutan. Menurut Christiawan, ketiga bentuk lanskap budaya ini merupakan manifestasi dari kearifan lokal yang menuntun masyarakat untuk hidup selaras dengan hutan (Christiawan 2017:876).

Berbeda dengan studi-studi yang telah dikemukakan di atas, kajian ini membahas tentang kearifan lokal yang terdapat pada masyarakat Boti. Secara lebih khusus, tulisan ini mengungkap kearifan lokal yang ditunjukkan melalui struktur, fungsi, dan simbolisasi rumah adat. Selanjutnya, pembahasan rumah adat Boti, yang disebut ume kbubu (rumah bulat), dikaitkan dengan isu ketahanan pangan dan bencana.

Penelitian terdahulu tentang masyarakat Timor telah dilakukan oleh Middelkoop. Menurut Bois (1964), dalam korpus data yang disajikan, Meddelkoop memberi interpretasi singkat tentang beberapa istilah yang khusus ditemui dalam bahasa Dawan (Uab Meto). Istilah-istilah tersebut dapat memberi gambaran mengenai kebudayaan masyarakat Dawan, serta upacara-upacara ritual yang dilakukan. Penelitian ini bersifat pengumpulan data, yang kemudian disusun secara acak tanpa diklasifikasi ke dalam cerita rakyat atau tuturan ritual. Selain itu, Middelkoop pun tidak menginterpretasi data tersebut secara secara terperinci.

Pembahasan yang lebih spesifik tentang masyarakat Boti dapat dilihat dari dua tulisan berikut ini. Pertama, kajian Iswanto et al. (2018) yang memberikan gambaran tentang ritual kematian nen fen nahat neu nitu, yakni doa memberi makan arwah. Di sini dijelaskan tentang keunikan masyarakat Boti dan bagaimana penggunaan teori 
semiotik kognitif dalam menggambarkan sebuah tuturan ritual. Kedua, tulisan Iswanto dan Alexander (2020) mengenai masyarakat Boti, yang menjelaskan tentang kehidupan masyarakat Boti yang masih melaksanakan seluruh ritus siklus kehidupan tanpa dipengaruhi oleh eksistensi masyarakat modern. Meskipun kedua tulisan tersebut tidak secara jelas memberikan penjelasan tentang ume $k b u b u$ sebagaimana yang menjadi fokus dalam penelitian ini, tetapi tulisan yang kedua dapat memberi gambaran tentang karakteristik masyarakat Boti yang menunjukkan adanya kemandirian dalam pengelolaan makanan pokok, kegiatan masyarakat, dan pendukung sosial lainnya.

Adapun kajian-kajian terbaru tentang kebencanaan menawarkan pendekatan dan analisis yang cukup beragam. Pendekatan behavioristik. Misalnya, pernah dikemukan oleh para ahli untuk memetakan pendekatan yang efektif dalam penanganan bencana (Bavel et al. 2020). Namun, penjelasan mereka mengenai pendekatan perilaku sosial dalam menanggapai bencana dianggap masih kurang spesifik. Meskipun demikian, beberapa prinsip metodologi yang telah diterapkan tersebut dapat digunakan dalam penelitian ini.

Kajian terbarukan lainnya mengaitkan xenophobia atau ketakutan terhadap orang asing dengan bencana berupa pandemi Covid-19 (Noel 2020). Pendapat ini dapat dijadikan sebagai pandangan yang memiliki kaitan dengan tatanan sosial yang ketat dan ketahanan terhadap wabah penyakit. Di sini terlihat pula bahwa struktur sosial sangat memengaruhi perilaku individu. Dalam kaitannya dengan masyarakat Boti, selama ini struktur sosial yang berlaku merupakan pengatur gerak masyarakat dalam melakukan berbagai tindakan, termasuk dalam menghadapi bencana.

Kearifan lokal, tidak hanya menjelaskan pola-pola suatu masyarakat, siklus kehidupan, dan kognisi sosial, tetapi juga bagaimana masyarakat tersebut beradaptasi dengan lingkungannya. Secara fenomenologis, masyarakat asli bersinggungan dengan konteks "kemodernan" yang berada di luar lingkungan hidup mereka seharihari. Hal-hal yang terjadi di luar ranah masyarakat asli akan memengaruhi persepsi dan menggeser pola-pola tertentu yang selama ini telah ada di masyarakat tersebut. Demikian pula dengan ume kbubu, khususnya dalam kaitannya dengan ketahanan bencana, yang tentu bersinggungan pula dengan berbagai elemen yang terdapat di masyarakat (Nugroho dan Negara 2020: 2-5).

Ketahanan pangan (food security) adalah isu yang juga berkaitan dengan ketahanan bencana. Dalam hal ini, yang dimaksud dengan ketahanan adalah kemampuan yang dimiliki masyarakat yang berada dalam kondisi rawan bencana untuk beradaptasi, baik dengan cara bertahan maupun melakukan perubahan yang diperlukan, guna mencapai dan mempertahankan suatu fungsi dan struktur dalam tingkat tertentu, dalam batas yang dapat diterima (Nurwahyudi 2018:10). Adapun ketahanan pangan menurut pendapat Salim dan Ariani (2002:12) ialah "tersedianya pangan dalam 
jumlah dan kualitas yang cukup, terdistribusi dengan harga terjangkau dan aman dikonsumsi bagi setiap warga untuk menopang aktivitasnya seharihari sepanjang waktu."

Masyarakat asli Boti menggunakan kearifan lokal untuk dapat mengelola sumber makanan selama setahun atau satu kali masa tanam. Pengelolaan sumber makanan dimulai dari menentukan seberapa banyak jagung akan ditanam, waktu panen, penyimpanan, dan pengolahan makanan. Masyarakat Boti menyimpan jagung dalam ume $k b u b u$. Jagung yang disimpan dalam ume kbubu dapat bertahan hingga satu tahun. Teknik pengawetan jagung dalam ume kbubu menggunakan teknik pengeringan dengan asap. Selain itu, jagung diikat dalam ikatan tertentu, biasanya 4 atau 8 bulir jagung perikatan.

Berdasarkan gambaran ringkas di atas, pertanyaan utama dalam penelitian ini adalah bagaimana ume kbubu sebagai wujud kearifan lokal masyarakat Boti dapat menjaga ketahanan pangan dan melindungi masyarakat dari bencana? Dalam upaya menjawab pertanyaan tersebut, penelitian ini diharapkan dapat pula memberi penjelasan mengenai struktur, fungsi dan simbolisasi ume kbubu sebagai rumah adat masyarakat Boti. Oleh karena itu, sinkronisasi yang ditekankan dalam penelitian ini adalah antara konsep ume kbubu sebagai rumah adat dengan ume kbubu yang mampu mendukung ketahanan pangan dan bencana. Dasar pemikirannya, rumah adat bukanlah sekadar kontruksi bangunan hasil pikir masyarakat lokal yang berbentuk fisik. Lebih jauh dari itu, di dalamnya terdapat nilai dan makna yang sudah teruji dari generasi ke generasi.

Kebaruan dalam penelitian ini terletak pada interpretasi terhadap eksistensi ume kbubu yang dikaitkan dengan ketahanan terhadap bencana dan ketahanan pangan, serta penalaran akademis tentang struktur dan fungsi ume kbubu sebagai rumah adat dan simbolisasi tatanan sosio-kultural. Tulisan ini ingin memperlihatkan bahwa ume kbubu dengan struktur, fungsi, dan simbolisasinya, yang diperkuat dengan tatanan masyarakat yang baik, merupakan strategi pertahanan dalam menghadapi krisis pangan dan bencana lain, seperti penyakit menular.

\section{B. METODE}

Metode yang digunakan dalam penelitian ini ialah deskriptif kualitatif. Penelitian deskriptif memiliki beberapa pendekatan. Dalam penelitian ini pendekatan yang digunakan ialah fenomenologi. Fenomenologi menekankan bukan apa yang tampak, tetapi apa yang berada di balik yang tampak. (Gallagher dan Zahavi 2007:5).

Lebih lanjut, penelitian lapangan memiliki karakteristik tersendiri, terutama penelitian sensitif topik (sensitive topic research). Dalam penelitian sensitif topik, fokus utamanya adalah data yang merupakan bahan kajian penelitian. Sebuah penelitian dikategorikan sebagai penelitian topik sensitif (baik dalam paradigma data sensitif maupun metode dan teknik pemerolehan data). Sebagai contoh, data penelitian berupa tuturan ritual yang turut dikaji dalam penelitian 
ini dapat dikategorikan sebagai sensitif karena berkaitan dengan peristiwa yang hanya dilaksanakan pada waktu tertentu, dengan pelibat yang sudah ditentukan, dan aturan-aturan yang ketat. Kelompok masyarakat Boti tergolong masyarakat yang memiliki serangkaian aturan adat, sehingga data ritual, keterbukaan memberikan istilahistilah ume kbubu sulit didapatkan. Orang Boti beranggapan bahwa istilah adat bersifat sakral dan memiliki daya 'magis' bila dibagikan kepada orang yang kurang tepat.

Dalam penelitian ini, sumber data primer diperoleh dari hasil wawancara dan secara bersamaan dilakukan pula observasi. Metode dan teknik pengambilan data primer dilakukan dengan berbagai pendekatan, terutama mempertimbangkan narasumber yang diwawancarai. Metode wawancara menggunakan metode simak libat cakap pendekatan in depth interview (Karcher, Kirilova, dan Page 2019). Metode wawancara in depth interview yang diterapkan dalam penelitian ini dilakukan dengan cara membuat pertanyaan pokok sebagai instrumen. Daftar pertanyaan pokok ini hanya berfungsi sebagai pedoman dalam wawancara, tetapi pada pelaksanaannya pertanyaan yang diajukan terus berkembang hingga mencapai tingkat data jenuh atau terpenuhinya kedalaman data penelitian yang diinginkan. Teknik pengumpulan data yang seperti ini yang juga ditekankan oleh Karcher et al. (2019).

Selain itu, secara bersamaan dilakukan observasi dengan teknik tabel observasi. Teknik ini tidak dilakukan secara tunggal yang hanya mengandalkan satu tabel dari beberapa aspek yang telah ditentukan, tetapi dilakukan dengan observasi yang diperluas. Teknik ini bergerak dari satu fenomena ke fenomena lain dengan menggunakan instrumen yang berbeda. Pendekatannya harus dari yang bersifat umum ke khusus. Tingkat kedalaman observasi sangat ditentukan oleh waktu, keterbukaan narasumber saat diwawancarai, dan berbagai pendekatan sosiokultural yang sangat ditentukan peneliti dan peristiwa budaya yang terjadi.

Penelitian ini juga mengembangkan metode pengambilan data dengan teknik wawancara diperluas (expanded interview observation). Metode ini dikembangkan dengan tujuan memperoleh data penelitian yang sulit, yang hanya dapat diberikan oleh narasumber utama sendiri. Teknik yang dikembangkan berupa perekaman individual. Menurut Umanailo (2019:1-2), dengan cara ini data akan dapat diperoleh, sehingga peneliti terhindar dari akses terhadap data yang minim bahkan tidak memperoleh data yang diperlukan.

Fokus perolehan data dalam penelitian ini meliputi: (1) etimologi budaya, yakni istilah khas, makna, dan konteksnya dalam teks budaya masyarakat Boti; (2) observasi secara luas tentang ume kbubu, kehidupan sosio-kultural, aturan adat, upacara adat, dan sistem sosial. Narasumber utama dalam penelitian ini ialah Bota Benu (85 tahun) yang menjabat sebagai meo (panglima kerajaan). Adapun narasumber pendukung berjumlah dua orang, yaitu Namah Benu (usif atau raja/kepala suku Boti) dan Paulus Pobas (budayawan masyarakat Boti). Selain data mengenai tuturan ritual, dari 
mereka diperoleh pula data penting lain yang diperlukan, sesuai dengan fokus penelitian ini.

Penerapan paradigma metodologi seperti ini akan membawa kita kepada temuan baru secara metodologis. Temuan kebaruan menjadi tuntutan dalam penyelesaian sebuah penelitian modern. Pada kenyataannya, temuan kebaruan tidak selalu harus berupa hasil analisis, tetapi bisa juga berupa kebaruan teori yang dibangun dari theoretical framework untuk analisis data yang kompleks, metodologi yang mencakup kebaruan alat ukur (instrument measure), kebaruan teknik pengumpulan dan analisis data, atau bisa juga berupa kebaruan data (El Qaoumi et al. 2018).

Dalam penelitian ini, sebagaimana penelitian sensitif topik yang telah dijelaskan sebelumnya, terdapat karakter data yang hanya dikuasai oleh satu atau dua orang. Data tentang tuturan ritual Boti, misalnya, hanya dikuasai oleh beberapa orang saja. Lokasi penelitian pun sulit dijangkau, dengan kondisi masyarakat yang sulit berinteraksi dan tertutup terhadap eksplorasi penelitian. Oleh karena itu, diperlukan waktu yang lama untuk dapat memperoleh data penelitian yang dibutuhkan dan sumber daya pendukung yang dapat digunakan oleh peneliti untuk mengatasi permasalahan dalam pengumpulan data. Dapat dikatakan bahwa temuan kebaruan dalam penelitian ini adalah berupa kebaruan dalam skema observasi, wawancara, dan triangulasi. Praktik dari temuan kebaruan ini berhasil untuk memperoleh data baru khususnya yang tergolong sensitif, mengingat masih minimnya penelitian tentang suku Boti yang pernah dilakukan sebelumnya.

Saat melakukan penelitian lapangan, tantangan yang harus dihadapi ialah bagaimana memperoleh data sensitif, misalnya data tentang ritual yang sakral, ataupun data tentang istilah-istilah adat yang sulit diperoleh karena adat tersebut tidak boleh diikuti oleh orang luar dan tidak bisa diberikan secara sembarangan. Dalam kondisi seperti ini, peneliti harus membuat skema khusus untuk observasi, wawancara, dan triangulasi agar data sensitif dapat diperoleh. Gambaran tentang skema tersebut dapat dilihat pada gambar 1 .

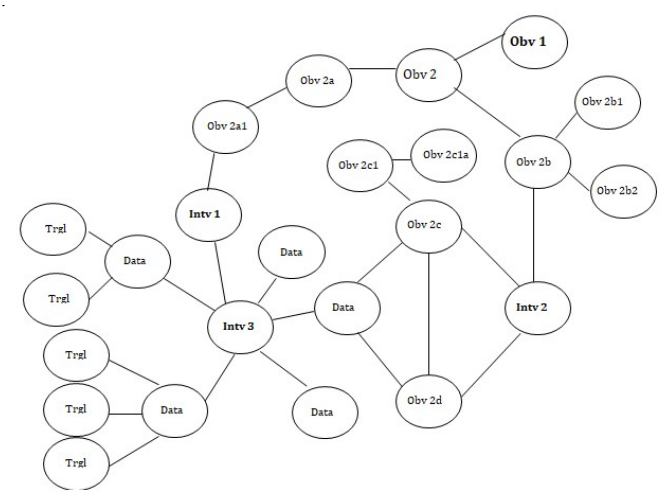

Keterangan:

Obs.:observation

Int.: interview

Trgl.: triangulation

Gambar 1. Skema extended observation, extended interview, dan multiple triangulation pada penelitian sensitive topic, yang menjadi temuan kebaruan (novelty). Sumber: Iswanto 2018.

Selanjutnya, data yang telah diperoleh ditranskripsi dari bahasa $U a b$ Meto yang merupakan bahasa sastra lisan tinggi ke dalam bahasa Indonesia. Hasil transkrip data yang berupa susunan kata tersebut kemudian 
dideskripsikan, bergerak secara induktif, dari yang bersifat umum menuju ke khusus.

\section{HASIL DAN BAHASAN}

\section{Struktur Sosial Masyarakat Boti}

Secara geografis, Desa Boti terletak di Kecamatan Kie, Kabupaten Timor Tengah Selatan (TTS), Provinsi Nusa Tenggara Timur (NTT). Luas wilayah Boti $17,69 \mathrm{~km}^{2}$ dan terbagi atas empat dusun, yaitu Dusun Boti A, B, C, dan D. Wilayah Dusun Boti A dan B dikategorikan sebagai Boti Dalam, sedangkan wilayah Dusun Boti C dan D dikategorikan sebagai Boti Luar. Kedua wilayah ini dipisahkan oleh Sungai Neo Bet Pena. Wilayah Boti Dalam, tepatnya Dusun Boti A, adalah pusat pemerintahan Kerajaan Boti (sonaf) sekaligus menjadi pusat pemerintahan desa.

Penduduk Desa Boti secara keseluruhan berjumlah 2.063 jiwa, yang terbagi dalam 536 Kepala Keluarga (KK). Kelompok Boti Dalam berjumlah $77 \mathrm{KK}$ atau 350 jiwa, sedangkan sisanya dikategorikan sebagai Boti Luar. Suku Boti memiliki keunikan tersendiri yang tidak hanya terkait dengan penyembahan atau kepercayaan terhadap roh leluhur yang ilahi, tetapi juga dalam tatanan sosial-budaya dan pengetahuan yang bersumber dari kedekatannya dengan alam.

Secara adat, kehidupan masyarakat Boti dipimpin oleh $u$ sif sebagai kepala suku. Berbagai kegiatan yang terjadi di dalam lingkungan masyarakat harus sepengetahuan sang raja. Raja berperan mengatur berbagai aspek kehidupan warga mulai dari kelahiran, perkawinan, hingga kematian. Sang usif mempunyai tanggung jawab sosial dan moral bagi kesejahteraan dan kebaikan warganya.

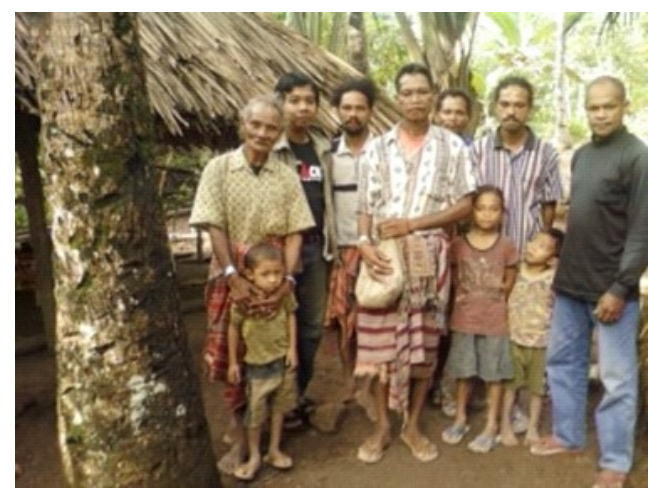

Gambar 2. Foto peneliti, penerjemah, dan masyarakat Boti. Sumber: dokumentasi penulis.

Struktur sosial masyarakat Boti menempatkan panglima (meo) sebagai pengawal raja. Tugas meo ialah mengamankan wilayah/ lingkungan kerajaan dan desa secara keseluruhan dari berbagai bahaya yang mengancam, terutama serangan musuh dari luar. Para meo ditempatkan di setiap perbatasan kerajaan. Pada wilayah barat ditempatkan meo feto (panglima rendah) yang dikepalai oleh Bernadus Benu. Adapun di wilayah timur terdapat meo mone (panglima tinggi) yang dikepalai oleh Bota Benu. Tugas lain para meo adalah mengamankan perintah raja dan sebagai tangan kanan raja. Apabila ada kegiatan-kegiatan di lingkungan kerajaan yang berhubungan dengan pihak luar, kegiatan itu dikoordinasi oleh para meo.

Selain meo, terdapat pula beberapa orang lopo sebagai pembantu wilayah administratif. Mereka bertindak sebagai pelaksana aturan kerajaan di tingkat wilayah. Dengan demikian bila terjadi masalah-masalah di tingkat wilayah, para lopo berkoordinasi dengan usif 
untuk segera melakukan berbagai tindakan yang diperlukan. Pada lingkungan sonaf, terdapat pula para pelayan kerajaan yang terdiri atas marga-marga, yakni Neolaka, Tefamnasi, dan Boentekan. Tugas mereka adalah menyediakan dan mengatur persediaan makanan serta minuman di istana. Mereka pula yang mengurus dan menjaga kebun dan ternak sang raja (Iswanto 2020:88-89).

\section{Kearifan Lokal dalam Tatanan Sosial dan Budaya Masyarakat Boti}

Pada masyarakat Boti, khususnya kelompok Boti Dalam, keseluruhan ritual masih dilaksanakan. Pelaksanaannya tidak hanya sebagai kewajiban, tetapi juga sebagai kontrol sosial dan budaya. Dalam ritual-ritual yang berkaitan dengan siklus kehidupan yang terdiri dari lahir, kawin, dan mati, hukum adat juga diberlakukan di dalamnya.

Penerapan hukum adat juga masih efektif untuk mengendalikan perilaku sosial yang dianggap menyimpang. Sebagai contoh, sanksi adat yang bagi pencuri di Desa Boti yang bukan berbentuk hukuman fisik, tetapi mengarah kepada hukuman psikososial. Jika seseorang didapati mencuri pisang, maka seluruh pisang yang ada di masyarakat harus diberikan kepada orang tersebut. Hal ini dilakukan berdasarkan persepsi bahwa orang yang mencuri adalah orang yang membutuhkan. Justru dengan cara seperti ini, sangat sedikit tindak kejahatan dan penyelewangan sosial yang terjadi pada masyarakat Boti.
Hukuman sosial biasanya akan disertai dengan hukuman adat yang dianggap sakral. Sebagai contoh, pada peristiwa masyarakat Boti yang kedapatan mencuri hasil panen orang lain. Orang tersebut akan diajak berbicara secara adat di rumah pertemuan atau di bawah pohon beringin besar. Walaupun terlihat seperti pertemuan biasa, masyarakat yang menghadiri kegiatan tersebut menjaga sikap masing-masing agar terhindar dari hukuman adat leluhurnya. Peristiwa-peristiwa hukum seperti inilah yang dipersepsikan masyarakat Boti sebagai sesuatu yang sakral.

Wujud lain dari kearifan lokal yang dimiliki oleh masyarakat Boti adalah konsep pembagian hari menjadi sembilan hari, yaitu neon kaet (hari keramat), neon li'ana (hari anak), neon ai (hari api), neon onen (hari doa), neon masikat (hari bersaing), neon suli (hari perdamaian), neon pah (hari bumi), neon besi (hari besi/logam), dan neon snasat (hari perhentian). Pada neon pah (hari bumi), semua masyarakat suku itu dilarang menebang pohon dan merusak lingkungan. Pada neon li ana (hari anak), para orang tua dilarang memarahi dan memukul anak-anak. Pada neon suli (hari perdamaian), warga tidak boleh sembarang bertutur kata, sehingga tidak terjadi salah paham dan pertengkaran. Jika terjadi pertengkaran, maka semuanya dapat diselesaikan secara adat tanpa sanksi atau denda. Neon snasat (hari perhentian) dan neon kaet (hari keramat) adalah hari-hari yang dikhususkan untuk sejenak berdoa. Berdoa pada masyarakat Boti adalah kegiatan berdiam diri pada hari 
perhentian. Doa atau dalam bahasa Dawan dikenal dengan istilah onen merupakan kegiatan yang sakral. Pada saat seperti ini masyarakat Boti secara individu menenangkan diri dan tidak ingin diganggu oleh aktivitas sosial lainnya.

Pada setiap hari kesembilan, semua penganut Halaika diharuskan untuk berkumpul di balai pertemuan untuk melakukan pertemuan (eku tefas). Warga menyebutnya sebagai hari perhentian karena hari tersebut dianggap kurang baik (neon leuf). Mereka hanya diperbolehkan untuk berkumpul (neon tokos) untuk mendengarkan nasihat sang raja. Setiap hari kesembilan, warga dilarang melakukan aktivitas di kebun, beternak, bahkan tidak diizinkan makan dan minum. Semua warga akan puasa (tidak makan dan minum) dari pagi hingga sore.

Masyarakat Boti juga dikenal memiliki kemampuan astronomi dalam membaca gugus bintang dan bulan. Kearifan lokal ini digunakan untuk pertanian dan menyiapkan persediaan bahan pangan. Misalnya, apabila curah hujan banyak, masyarakat harus menyiapkan persedian jagung yang cukup dalam ume kbubu dan mengantisipasi bencana tanah longsor. Demikian pula di saat curah hujan sedikit yang dapat menimbulkan bencana kekeringan. Ilmu perbintangan ini diturunkan dari generasi ke generasi. Meskipun begitu, tidak semua orang memiliki kecakapan tersebut.

Sistem perhitungan musim pada masyarakat Boti didasarkan pada posisi bulan dan gugus bintang. Masyarakat Boti mengenal dua gugus bintang, yaitu teta dan ma' la'fu. Musim kemarau dan musim tanam ditentukan oleh posisi kedua gugus bintang tersebut. Jika keduanya berada di sebelah timur, maka pertanda sedang musim hujan. Sebaliknya, jika berada di sebelah barat pertanda sedang musim kemarau. Tuturan yang menjadi falsafah hidup masyarakat Boti yang berhubungan dengan kedua gugus bintang ini ialah kuin hitu mat hitu apinat aklahat, kuin hitu mat hitu amelat aekat (tujuh lapis mata tujuh bersinar terang, tujuh lapis mata tujuh penghapus air mata duka).

Makna astronomi budaya ini sangat kuat bagi masyarakat Boti. Istilah astronomi budaya yang dimaksud di sini merupakan kemampuan membaca rasi bintang dan dikaitkan dengan peristiwa budaya, seperti panen dan siklus kehidupan. Berkaitan dengan hal tersebut, makna budaya apinat aklahat (bersinar terang) berkaitan dengan eksistensi manusia di alam semesta.

Benda-benda langit dipersepsikan sebagai sesuatu yang adikodrati. Masyarakat Boti menyebutnya dengan uis neno (Tuhan langit). Kata neno pada uis neno bermakna ganda, yaitu "langit" dan "hari". Kemunculan makna ganda tersebut disebabkan adanya pertautan dua konsep berbeda yang linear dalam realitas pengamatan indra. Dalam hal ini makna orisinal dikembangkan menjadi makna baru tanpa menimbulkan pertentangan makna. Makna figuratif polisemi dibentuk dari kata neno, yakni "langit" atau "hari", yang mengacu pada referen langit sebagai wujud yang konkret. Adapun istilah neno yang dimaknai sebagai "hari" muncul sebagai makna figuratif linear dari bentuk orisinal istilah neno yang berarti "langit". 
Benda-benda langit adalah penuntun kehidupan. Siklus bercocok tanam, banyaknya jumlah jagung yang akan ditanam, intensitas hujan, bencana yang mungkin terjadi sebagai akibat intensitas hujan pada lereng-lereng bukit, proses kelahiran, pelaksanaan ritual adat, dan siklus waktu (pembagian sembilan hari), sangat ditentukan oleh posisi gugus bintang tersebut. Makna budaya selanjutnya tertuang dalam frasa amelat aekat yang berarti penghapus air mata (duka). Makna tersebut menunjuk pada tanda yang diberikan oleh benda langit yang akan menentukan kehidupan dan membawa harapan hidup.

Sistem penandaan adikodrati masyarakat Boti merupakan pembedahan persepsi dalam ruang lingkup religi. Masyarakat "asli" menghayati Tuhan bukan melalui ajaran-ajaran eksplisit melainkan melalui kenyataan keseharian. Kepercayaan yang bersumber baik dari mitos-mitos, ritus-ritus, doa-doa, serta kebiasaan lainya membangun citra Tuhan sebagai Sang Adikodrati. Kondisi yang sama ditemukan pula pada masyarakat Boti sebagaimana tertuang dalam tuturan-tuturan ritual mereka. Dalam hal ini persepsi mengenai Tuhan mereka wujudkan melalui media bahasa sebagai ungkapan kepercayaan. Tidak hanya itu, kesakralan hidup sebagai bagian dari religiositas ditata dan dipelihara sedemikian rupa dan dinyatakan dalam tanda-tanda. Keterjalinan makna antartanda merupakan pengetahuan bersama sebagai dasar persepsi sosiologis.

Sesuai dengan topik kajian, bagian selanjutnya dari tulisan ini akan berfokus pada kearifan lokal masyarakat Boti yang diwujudkan melalui bangunan rumah adat ume kbubu dan kompleks pemukiman yang terbentuk di sekitarnya. Pembahasan tentang struktur fisik ume kbubu diharapkan dapat menunjukkan karakter masyarakat Boti yang adaptif dengan lingkungan alam. Selain itu, struktur bangunan rumah adat ini juga merepresentasikan pengetahuan tradisional masyarakat Boti, khususnya keterampilan dalam membangun tempat penyimpanan yang mampu menjaga kualitas bahan pangan dalam jangka waktu yang relatif panjang. Adapun pembahasan tentang fungsi dan simbolisasi ume kbubu diharapkan dapat memberikan gambaran tentang keterkaitan antara kearifan lokal ume kbubu dengan upaya masyarakat Boti dalam menjaga ketahanan pangan dan bencana.

\section{Ume Kbubu: Struktur, Fungsi dan Simbolisasinya}

\section{a. Struktur Bangunan Ume Kbubu}

Struktur rumah bulat ume kbubu dapat dideskripsikan mulai dari bagian fondasi baki. Konstruksi fondasi ume kbubu ialah batu susun yang membentuk lingkaran. Batu yang digunakan haruslah solid dan mudah dijumpai. Susuan batu ini kurang lebih tingginya $20-40 \mathrm{~cm}$. Batu yang dipilih adalah batu yang sangat kuat yang mampu menopang konstruksi bangunan di atasnya. Ketinggian fondasi ini juga berfungsi sebagai penahan air dan dan aman dari binatang pengerat. Bagian atas fondasi disebut lantai nijan yang menggunakan urukan tanah. 
Strukur fondasi berbentuk bulat dengan lantai yang dipadatkan dan sambungannya menggunakan teknik ikatan. Konstruksi seperti ini membuat struktur bangunan ume kbubu lebih tahan gempa karena dapat meredam gesekan antarsambungan dengan lebih baik jika dibandingkan dengan rumah persegi dengan sambungan permanen.

Bagian selanjutnya disebut dengan tiang $n i$. Tiang yang menghubungkan antarlantai dan sambungan kayu di atasnya disebut ni anaf. Tiang ini terdiri dari empat buah kayu besar yang ditancapkan secara simetris pada empat sisi. Ni anaf harus tertancap secara dalam dan sangat kuat. Secara arsitektur $n i$ anaf berfungsi sebagai penyangga tingkat kedua. Tiang utama atau penyangga berjarak 1,5-2,5 m. Pemilihan material untuk tiang penyangga menggunakan kayu merah dan kayu putih. Kedua jenis kayu ini digunakan karena kekuatan dan daya tahan terhadap cuaca. Kayu yang digunakan haruslah tegak lurus dan memiliki cabang pada ujungnya, karena akan digunakan untuk menopang atap yang dikenal dengan istilah sui'.

Ketinggian tingkat dasar hanya setinggi orang dewasa dan dihubungkan dengan sebuah tangga. Pada tingkat kedua terdiri dari dua penopang suit yang diletakan melintang di atas $n i$ anaf. Teknik ikatan digunakan pada sambungan ni anaf ke suit. Pada prinsipnya suit berfungsi sebagai segmen penghubung dengan bagian di atasnya.

Prinsip tegak pada tiang $n i$ anaf diubah menjadi melintang dengan menambah dua batang tiang suit. Selain sebagai segmen penghubung, suit juga berfungsi sebagai alas ikat bagian melintang lainya yang disebut nomaf. Nomaf harus diikatkan sangat kuat pada suif. Nomaf juga berfungsi sebagai dasar lantai pada tingkat atas dari ume kbubu.

Teknik berlapis pada tingkat atas akan memperkuat alas yang nantinya digunakan untuk menyimpan jagung dalam jumlah yang banyak untuk persediaan satu tahun hingga masa panen berikutnya. Tingkat pertama dan kedua pada ume kbubu dihubungkan dengan tangga elak yang cukup kecil dan hanya digunakan untuk naik atau hanya sekadar mengambil jagung di tingkat kedua. Selain itu ada juga yang disebut tangga bambu elak se'at, yakni sebuah bambu dengan 4-5 lubang sebagai pijakan naik.

Tiang vertikal nomaf diikat lagi dengan enam buah tunis dengan posisi membujur dan melintang terhadap kayu penopang nomaf. Struktur suit diikatkan pada nomaf dan tunis membentuk tiga lapisan yang kokoh yang tidak hanya menopang tingkat atas dari ume kbubu, tetapi menjadi pemberat dan pengokoh tiang ni anaf. Lapisan melintang dan membujur yang diikat sangat kuat diperlukan sebagai penopang berat atap yang cukup berat. Konstruksi atap disangga oleh sebuah tiang vertikal yang disebut tuni. Posisi tunis berada di tengah diameter lingkar lantai dan diletakkan pada tingkat atas. Tiang penopang atap tunis berdiri dengan sebuah kayu alas tiang tegak sebagai pusat atap disebut pauf yang diikat dari alas kayu yang sejajar dengan tunis.

Penjelasan selanjutnya adalah mengenai dinding dari ume kbubu yang 
dikenal dengan istilah niki. Dinding dipasang melingkar pada tiang ni ana. Konstruksi ini juga ditopang dengan bilah-bilah kayu yang terbuat dari bambu. Dengan konstruksi seperti ini dinding akan lebih kuat dari terpaan angin dan perubahan cuaca. Konstruksi dinding tidak simetris. Pada satu sisi ketinggiannya antara $0,50-0,80 \mathrm{~m}$, sedangkan dinding yang berada di dekat pintu ketinggiannya bertambah hingga $1 \mathrm{~m}$. Material yang digunakan untuk dinding antara lain ialah bambu yang diserut dan disusun, batang kayu pohon pinang, pelepah gewang, dan kulit kayu. Pada bagian bawah atau ujung dinding diberi batu tumpu untuk menghindari rayap.

Bagian atap disebut humusu yang dibuat membujur hingga hampir menyentuh tanah. Atap dibuat berbentuk kerucut menyesuaikan bentuk denah dan rangka atap. Puncak atap mempunyai dua bentuk, yakni bulat seperti sanggul wanita dan pelana atau palungan terbalik. Atap yang berbentuk bundar atau kerucut secara arsitektur akan melindungi dari panas dan udara dingin.

Pada bagian atap terdapat konstruksi nono ana yang biasanya dibuat dari susunan kayu pohon cemara dengan diameter 2-4 $\mathrm{cm}$ yang diikat melingkar. Nono ana dalam rancang bangun atap berfungsi sebagai kerangka atap dan sebagai rangka untuk mengikat homusu. Selain dari nono ana, pada bagian atap adapula konstruksi nono tetu yang melengkapai kontruksi nono ana atau konstruksi ikat melingkar pada bagian tengah, sehingga atap tidak mudah rusak atau roboh. Bagian lain yang disebut suaf merupakan kayu bulat lurus sebagai penyangga semua nono. Konstruksi melintang juga digunakan pada nono yang dikenal dengan sebutan takpani. Bagian akhir dari atap ialah hun yang dibuat dari alang-alang.

Struktur bangunan ume kbubu dapat dilihat pada gambar di bawah ini.

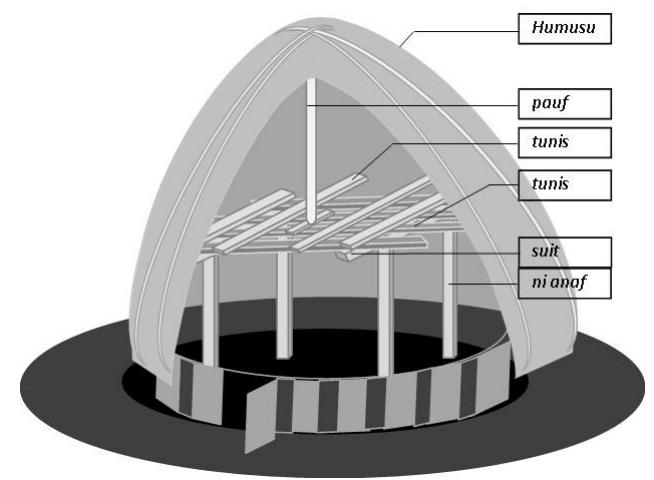

Gambar 3. Rumah bulat ume kbubu yang disebut juga rumah perempuan (ume bife) Sumber: ilustrasi Iswanto berdasarkan hasil penelitian.

\section{b. Fungsi dan Simbolisasi Ume Kbubu} Istilah rumah bulat ume kbubu disebut juga sebagai rumah perempuan atau ume bife. Alasan penyebutan tersebut terkait dengan fungsinya sebagai: (1) dapur; (2) tempat istirahat sementara untuk perempuan; (3) tempat mengatur bahan makanan yang akan dikelola; dan (4) tempat mengatur bahan makanan untuk satu tahun.

Lebih lanjut, ume kbubu juga dijadikan rumah bagi 40 hari kehidupan pertama bagi seorang bayi yang baru lahir. Masyarakat Boti percaya bahwa dengan cara ini, anak tersebut akan tumbuh menjadi lebih kuat di kemudian hari. Di tengah-tengah ume kbubu terdapat perapian yang bara apinya tidak boleh padam dan harus terus asap. Tidak hanya berfungsi mempertahankan suhu hangat di malam hari, bara 
yang terus menyala tersebut terkait pula dengan simbolisasi kehidupan.

Ume kbubu sebagai simbolisasi kehidupan masyarakat Boti juga tampak dari fungsi ume kbubu sebagai tempat penyimpanan bahan pangan. Berdasarkan hasil wawancara dengan Bota Benu pada Januari 2020 di Desa Boti, jagung atau dikenal dengan sebutan pena diletakan pada bagian atap dan dikelola dengan kehati-hatian sehingga harus cukup untuk satu tahun. Demikian pula halnya, jika seorang laki-laki meninggal dunia, maka tas kecil yang disebut dengan alu mama juga disimpan dalam ume kbubu. Tas kecil tersebut kemudian akan dibuka dalam ritual sef alu mama (membuka alu mama).

Dari penjelasan di atas, terlihat bahwa peranan ume kbubu tidak hanya sebagai rumah untuk menyimpan jagung, tetapi dapat diinterpretasi sebagai rumah kehidupan. Siklus hidup manusia terdiri dari lahir, bekerja, dan mati. Peristiwa kehidupan ini secara harfiah tidak terlepas dari fungsi ume kbubu sebagai rumah 40 hari pertama bagi bayi yang baru lahir, rumah penyimpanan sumber pangan, dan rumah penyimpanan benda-benda pribadi untuk diberikan kepada anak dan cucu setelah pemiliknya meninggal dunia.

Atribut-atribut seperti ini memberikan penjelasan tentang bagaimana masyarakat Boti menjalani kehidupannya. Gambaran tentang sistem sosial masyarakat Boti, misalnya, dapat dideskripsikan dari fungsi ume kbubu sebagai tempat penyimpanan bahan makanan (jagung) yang merupakan milik beberapa keluarga.

\section{Ume Kbubu sebagai Ketahanan} Pangan dan Ketahanan Bencana

Berdasarkan hasil observasi, tata pemukiman masyarakat Boti bentuknya berkelompok berdasarkan ikatan kekerabatan dan terpisah dalam kelompok-kelompok kecil. Satu kelompok kecil hanya terdiri dari lima sampai tujuh rumah tinggal dan satu ume kbubu. Kompleks permukiman memiliki pekarangan yang sangat luas dan dikelilingi oleh pagar pembatas untuk setiap satu kelompok kecil.

Setiap pertambahan keluarga baru di masyarakat Boti akan disertai dengan pembangunan rumah tinggal yang baru. Namun pada kenyataannya, pertumbuhan jumlah keluarga baru terjadi dengan sangat lambat. Hal ini tentunya berakibat pada jumlah anggota suku Boti yang juga semakin berkurang.

Struktur permukiman yang seperti ini mendukung terjaganya sistem budaya dan siklus ekologi. Tata ruang permukiman yang baik pun memberikan dukungan terhadap terbangunnya sistem kehidupan manusia yang lebih berkualitas, baik menyangkut ruang ekologi untuk tersedianya bahan pangan, kondisi kesehatan masyarakat, terselenggaranya aktivitas budaya, maupun kelestarian flora dan fauna yang penting bagi kelangsungan hidup manusia.

Hasil panen satu kelompok kecil tersebut disimpan dalam ume kbubu dan diatur pemakaiannya untuk keperluan selama satu tahun. Karakter alam yang minim dengan sumber air menjadi tantangan bagi masyarakat Boti dan kelompok masyarakat lain di Pulau Timor untuk dapat menghasilkan dan menyimpan bahan pangan agar 
ketersediaannya dapat memenuhi kebutuhan hidup mereka. Oleh karena itu, keberadaan tempat penyimpanan, yakni ume kbubu, menjadi sangat penting.

Masyarakat Boti sangat memperhitungkan segala sesuatu dengan cermat. Setiap gejala alam selalu dihubungkan dengan tatanan sosial. Fungsi meo (panglima) bukan hanya sebagai penjaga masyarakat Boti, tetapi juga sebagai penjaga tradisi, termasuk pengetahuan astronomi, perhitungan hari, pemimpin ritual, dan fungsi sosial budaya lainnya. Ritual panen fuah pah selalu dirayakan dengan sederhana dan hasil panen disimpan dalam ume kbubu. Dengan cara seperti ini, masyarakat Boti selalu berkecukupan dalam ketersediaan makanan pokok.

Kearifan lokal berupa pengetahuan dalam bidang pengawetan makanan pun tidak dapat dilepaskan dari keberadaan ume kbubu. Di situ, teknik pengasapan untuk mengawetkan jagung dipelajari dan dilestarikan. Sebagaimana telah dijelaskan pada bagian sebelumnya, salah satu fungsi dari lantai dasar ume $k b u b u$ adalah sebagai dapur untuk memasak. Kayu api yang digunakan selama proses memasak akan menjadi arang. Adat yang berlaku di kalangan masyarakat Boti mensyaratkan bahwa asap dari arang tersebut tidak boleh mati. Arang yang harus terus menyala itu menunjukkan makna budaya ume kbubu sebagai simbol kehidupan. Namun di sisi lain, secara fungsional bertujuan untuk mengawetkan makanan yang berada di bagian atap.

Cara menyimpan dan mengonsumsi jagung yang ada di dalam ume $k b u b u$ diatur secara khusus. Tiap empat bulir jagung diikat dan digunakan untuk makan satu keluarga. Proses memasaknya dengan ditumbuk menjadi jagung bose. Sistem pengawetan dan pemanfaatan yang seperti ini menjadi sistem ketahanan pangan masyarakat lokal.

Desa Boti terletak di kemiringan. Rumah-rumah didirikan dengan sistem fondasi kayu dan tatakan batu. Sistem atap yang ringan (terbuat dari kayu dan jerami) dan volume rumah yang kecil membuat bangunan rumah tahan terhadap bencana alam, misalnya guncangan gempa. Struktur bangunan ume kbubu dengan konstruksinya yang khas akan stabil jika dibangun pada topografi yang miring.

Struktur bangunan ume kbubu yang telah dipaparkan pada bagian sebelumnya, tidak hanya berkaitan dengan konstruksi bangunan semata. Struktur bangunan tersebut berkaitan pula dengan struktur sosial, tata spasial, dan ketahanan masyarakat. Rumah tinggal dibangun sedemikian rupa dengan tata spasial tertentu yang sangat mempertimbangkan kondisi ekologis. Tatanan dalam pembangunan ume $k b u b u$ secara tidak langsung memperlihatkan adanya keteraturan yang menjadi salah satu kekuatan dan wujud ketahanan dari masyarakat Boti. Dapat dikatakan bahwa tata spasial yang teratur tersebut menopang tatanan sosialnya. Siklus kehidupan yang tertata dan ketat dengan aturan-aturan adat, menjadi ruang kehidupan bagi masyarakat Boti.

Desa Boti adalah salah satu desa terbesar di Kab. TTS. Batas desa ditandai dengan keberadaan sungai dan lereng terjal. Keadaan geografis yang seperti ini membuat bangunan ume 
$k b u b u$ yang menjadi hunian masyarakat Boti dan kompleks permukiman yang terbentuk di sekitarnya cenderung terpisah dengan kelompok masyarakat lain yang terdapat di sekitarnya.

Masyarakat Boti pun mengenal dan menerapkan aturan yang ketat yang membuat kelompok masyarakat Boti cenderung tidak terlalu terbuka terhadap kelompok masyarakat lain. Masyarakat Boti sendiri terdiri atas kelompok Boti Dalam yang masih menganut agama Halaika dan Boti Luar yang sudah tidak menganut Halaika.

Adanya struktur sosial yang demikian turut membatasi interaksi sosial di antara kedua kelompok yang berbeda ini. Dengan keterbatasan interaksi sosial dan keterbatasan akses ke Desa Boti karena kondisi alam, secara tidak langsung membangun mekanisme ketahanan terhadap bencana. Kondisi kesehatan masyarakat, misalnya, dapat dikontrol dengan baik, termasuk di saat terjadinya bencana penyakit menular. Oleh karena itu, dapat dikatakan bahwa letak rumah yang tidak berdekatan, pemantauan dalam sistem sosial yang ketat, minimnya interaksi dengan orang yang berasal dari luar suku, serta pola hidup yang sederhana, secara logis mampu menghindarkan masyarakat Boti dari wabah penyakit.

Hal menarik yang penting didiskusikan lebih lanjut adalah bagaimana masyarakat Boti mampu menjaga perilaku mereka untuk tetap patuh terhadap aturan-aturan adat yang diterapkan dalam pembangunan ume kbubu serta yang mampu mempertahankan fungsi ume kbubu sebagai tempat penyimpanan bahan makanan.
Salah satu penjelasan yang dapat ditemukan adalah bagi masyarakat Boti ume kbubu menyimbolkan kehidupan dan relasi masyarakat Boti dengan Tuhan dan sesama. Gambar berikut ini merupakan interpretasi peneliti tentang bagian-bagian dari ume kbubu yang dapat menjelaskan pemikiran tersebut.

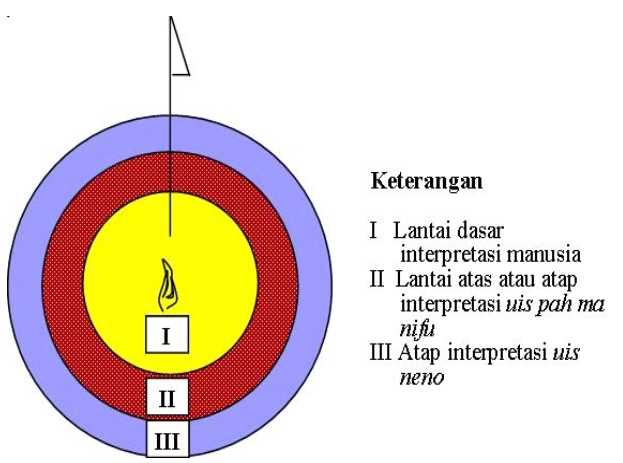

Gambar 4. Interpretasi ume kbubu. Sumber: ilustrasi Iswanto berdasarkan hasil penelitian.

Di bagian I, terdapat tempat memasak, tempat beristirahat seorang wanita (ibu), serta api atau arang yang tidak pernah padam. Di bagian II tersimpan jagung yang kering oleh asap yang dihasilkan dari api dan arang yang berada di bagian I. Selain itu, bagian II dipergunakan pula untuk menyimpan beberapa benda pusaka di antaranya alu mama, yakni tas kecil milik orang tua yang sudah meninggal. Di bagian III terdapat bumbungan sebagai interpretasi hubungan manusia, Tuhan dan kehidupan.

Ume kbubu sebagai kearifan lokal masyarakat Boti dalam menjaga ketahanan pangan menggambarkan paradigma masyarakat Boti sebagai manusia (antropologi) dan bagian dari alam (ekologi). Hal ini dapat dikaitkan dengan konsep pahmanifu, yakni tanah 
dan air, yang terdapat di masyarakat Boti. Konsep ini dikenal pula oleh masyarakat Indonesia dengan istilah tanah air. Atribut yang diberikan pada pahmanifu ialah pemelihara, yang diimani sebagai Tuhan dengan sebutan uis pah ma nifu. Konsep ini berkaitan dengan perilaku masyarakat Boti dalam menjaga dan mempelajari alam, serta tampak pula pada sistem permukiman, tata spasial, dan ritus budayanya. Keberadaan ume kbubu dapat diinterpretasikan sebagai upaya manusia mempersepsikan ruang ekologi berupa lahan kering dan letak geografis yang berada di lereng curam, serta religiositas masyarakat Boti.

Masyarakat Boti menyakini bahwa kehidupan akan baik jika tata spasial dan ritual di ume kbubu dijalankan dengan baik. Sebaliknya, pengalihfungsian dan penghentian pelaksanaan ritual akan mendatangkan bencana. Pelaksanaan siklus ritual yang ketat, baik dalam bidang pertanian maupun proses penyimpanan bahan pangan di dalam ume kbubu, adalah upaya untuk menjaga keseimbangan dan kesinambungan kehidupan, serta menghindarkan diri dari bencana.

Perilaku tersebut menjadi suatu kepercayaan yang kokoh pada masyarakat Boti. Jika pada akhirnya terjadi bencana, maka mereka akan melakukan ritual naketi, yakni bertanya kepada Sang Adikodrati dan mengoreksi tatanan spritual yang terlewati atau telah mereka tinggalkan. Proses siklus ritual kehidupan seperti ini, pada kenyataannya menjauhkan masyarakat dari berbagai bencana.

Tatanan sosial yang terkontrol akan memberikan kemudahan dalam pengendalian sumber daya alam. Struktur ume kbubu adalah simbol dari keteraturan dan berfungsinya sistem budaya pada masyarakat pendukungnya. Dengan kata lain, keberadaan ume $k b u b u$ menjadi simbol dari keteraturan hidup dan bagaimana perilaku sosial yang sepatutnya.

Sebagaimana diketahui, bencana alam seperti kekeringan dan tanah longsor mengancam ketahanan pangan di beberapa kawasan di dunia. Kearifan lokal masyarakat, seperti yang terdapat pada masyarakat Boti, dapat dijadikan cara pandang baru untuk memformulasikan konsep pangan bagi masyarakat Indonesia. Ketahanan pangan yang terjaga melalui keberadaan ume kbubu menjadi simpul untuk membaca perilaku sosial dan interakasi budaya pada masyarkat Boti. Ketaatan pada aturan sosial dan budaya yang sulit dilaksanakan secara ketat pada masyarakat modern di perkotaan, justru menjadi kunci dalam pemantauan bencana.

\section{SIMPULAN}

Kearifan lokal yang tercermin dalam ume kbubu dapat terlihat pada konsep struktur bangunan ume kbubu. Simbolisasi budaya menempatkan ume kbubu sebagai rumah kehidupan. Fungsi ini terkait dengan siklus lahir, hidup, dan mati. Atribut ume kbubu sebagai rumah lahir terlihat pada ume $k b u b u$ sebagai tempat tinggal bayi yang baru dilahirkan yang tinggal bersama dengan ibunya selama 40 hari. Atribut rumah kehidupan, yakni sebagai tempat menyimpan bahan makanan pokok (jagung) selama satu masa tanam. Adapun atribut rumah kematian, 
yakni sebagai tempat menyimpan barang-barang peninggalan orang tua yang sudah meninggal dan akan dibagikan kepada keluarganya setelah masa berkabung 40 hari. Fungsi-fungsi tersebut memberi pesan ketahanan masyarakat dalam menghadapi perubahan zaman, degradasi budaya, termasuk ketahanan masyarakat Boti sebagai masyarakat asli dalam kondisi ekologi yang rawan bencana.

Berkaitan dengan hal tersebut, keteraturan siklus kehidupan masyarakat Boti bersumber pada aktivitas masyarakat. Konstruksi ume $k b u b u$ dapat menjelaskan konstruksi sosio-kultural yang berkaitan dengan hukum dan tatanan sosial. Selain itu, konstruksi budaya juga menjelaskan nilai religiositas yang terdapat pada masyarakat Boti. Dalam hal ini, simbol kehidupan dilambangkan dengan api, sedangkan konstruksi atap yang menjulang hingga ke tanah menjadi penentu perilaku masyarakat. Ketaatan dan keteraturan adalah cara mempertahankan hidup dan upaya mempertahankan diri dari risiko bencana.

Kearifan lokal ume kbubu yang berkaitan dengan ketahanan pangan dapat dilihat dari fungsinya sebagai tempat penyimpanan jagung bagi keluarga. Berdasarkan struktur bangunan ume kbubu, lantai kedua digunakan sebagai tempat menyimpan makanan. Struktur ini juga dimaknai sebagai simbol pentingnya pena jagung bagi kehidupan masyarakat Boti. Ketaatan terhadap aturan penyimpanan, pengawetan, dan pengonsumsian jagung di ume kbubu membuat bahan pangan ini cukup untuk kebutuhan sepanjang tahun, bahkan sebagai persiapan menghadapi kemungkinan terjadinya krisis pangan yang disebabkan oleh bencana tertentu.

Selanjutnya, struktur bangunan ume kbubu merupakan bentuk adaptasi masyarakat terhadap lingkungan alam yang khas. Struktur bangunan ini menyesuaikan dengan keadaan geologi, yaitu perbukitan dan lereng yang curam. Konstruksi bangunan ume kbubu dibuat sedemikian rupa sehingga stabil berada di kondisi yang rawan bencana longsor tersebut. Pada bagian ini perlu dimaknai bahwa alam memiliki nilai spiritual bagi masyarakat Boti. Penyesuaian dengan nilai-nilai spiritual berarti beradaptasi dengan kejadiankejadian alam, termasuk bencana. Kesadaran masyarakat Boti ini menjadikan konsep dan tindakan yang mengarah pada ketaatan terhadap sesuatu yang adikodrati (alam) dapat terwujud dalam kehidupan masyarakat Boti.

\section{E. REKOMENDASI}

Beberapa rekomendasi dalam penelitian ini adalah sebagai berikut. Pertama, pemerintah perlu mengadopsi berbagai kearifan lokal yang dapat digunakan untuk mengatasi permasalahan yang berkaitan dengan ketahanan pangan dan bencana. Kedua, struktur pemukiman masya-rakat Boti yang memperhitungkan berbagai aspek ekologis patut diper-timbangkan dalam rangka penyelenggaraan pembangunan permukiman masyarakat di Indonesia. Ketiga, perlu dilakukan berbagai upaya untuk tetap melestarikan budaya asli masyarakat Indonesia dengan berbagai pendekatan dan pendayagunaannya. 
Rekomendasi untuk penelitian lanjutan adalah penelitian yang difokuskan pada aspek budaya lain pada masyarakat Boti yang berguna dalam menghadapi tantangan zaman. Topik seperti ini sangat penting untuk dipikirkan karena berkaitan dengan keberadaan kearifan lokal dan pembangunan berkelanjutan bangsa Indonesia. Pembangunan seharusnya tidak hanya difokuskan pada aspek material, tetapi juga manusianya.

\section{DAFTAR SUMBER}

Bavel, Jay J. van et al. 2020. "Using Social and Behavioural Science to Support COVID-19 Pandemic Response." Nature Human Behaviour 4(5):460-71.

Bois, Cora Du. 1964. "General and Ethnology: Head Hunting in Timor and Its Historical Implications. Part I. Introduction and Texts A, B and C (Pp. 1-124). Part II, Text D (Pp. 126-259).Part III, Texts E, P, Gi, Gii, and $\mathrm{H}$ (Pp. 260-423). P. Middelkoop." American Anthrophologist, 66(1): 1207.

Carbaugh, Donal. 2007a. "Cultural Discourse Analysis: Communication Practices and Intercultural Encounters." Journal of Intercultural Communication Research 36(3):167-82.

. 2007b. "From Cognitive Dichotomies to Cultural Discourses: Hofstede, Fougère and Moulettes in Conversation."
Journal of Multicultural Discourses 2(1):20-25.

Christiawan, Putu Indra. 2017. "The Role of Local Wisdom in Controlling Deforestation." International Journal of Development and Sustainability 6(8):876-88.

Dryhurst, Sarah et al. 2020. "Risk Perceptions of COVID-19 around the World." Journal of Risk Research 23(4):1-13.

E1 Qaoumi, Kenza et al., 2018. "Testing Evolutionary Theory of Household Consumption Behavior in the case of Novelty-Product charateristics approach". Journal of Evolutionary Economics 28(2):1-24.

Gallagher, Shaun, dan Dan Zahavi. 2007. The Phenomenological Mind: An Introduction to Philosophy of Mind and Cognitive Science. London: Routledge.

Ho, Evelyn Y., Pauline Luk, dan Mohan Jyoti Dutta. 2019. Speaking of Health in Singapore Using the Singlish Term Heaty. (July). Vancouver: Fairleigh Dickinson University Press.

Indrayuda. 2017. "The Existence of Local Wisdom Value Through Minangkabau Dance Creation Representation in Present Time." Harmonia: Journal of Arts 
Research and Education 16(2):143-52.

Iparraguirre, Gonzalo. 2016. "Time, Temporality and Cultural Rhythmics: An Anthropological Case Study." Time and Society 25(3):613-33.

Iswanto. 2020. "Tradisi Lisan Natoni dalam Tuturan Ritual Sium Ana pada Masyarakat Boti di Nusa Tenggara Timur". Walasuji: Jurnal Sejarah dan Budaya 11(1):87-96.

Iswanto dan Ferdinand Alexander. 2020. "Perspektif Inklusif Pendidikan Agama Kristen terhadap Teks Kerja pada Masyarakat Dawan di Nusa Tenggara Timur." Sabda: Jurnal Teologi Kristen 1(1):71-84.

Karcher, Sebastian, Dessi Kirilova, dan Christian Page. 2019. "Sharing and Managing Qualitative Data." Moynihan Institute of Global Affairs 2. Diunduh 3 Agustus, 2020 (https://surface.syr.edu/miga/2).

Leipold, Sina, Peter H. Feindt, Georg Winkel, dan Reiner Keller. 2019. "Discourse Analysis of Environmental Policy Revisited: Traditions, Trends, Perspectives." Journal of Environmental Policy and Planning 21(5):445-63.

Noel, Tiffany Karalis. 2020. "Conflating Culture with COVID19: Xenophobic Repercussions of a Global Pandemic." Social
Sciences \& Humanities Open 2(1):100-44.

Nugroho, Yanuar, dan Siwage Dharma Negara. 2020. "Urgent Need to Strengthen State Capacity: Learning from Indonesia's COVID19 Crisis." PERSPECTIVE: Researchers at ISEAS-Yusof Ishak Institute Analyse Current Events (66):1-10.

Nurwahyudi, Ragil. 2018. "Implementasi Program Desa Tangguh Bencana Aspek Lingkungan Hidup di Kabupaten Pati (Studi Kasus di Desa Babalan Kecamatan Gabus)." Tesis, Program Magister Ilmu Lingkungan, Sekolah Pascasarjana Universitas Diponegoro Semarang.

Oesterdiekhoff, Georg W. 2018. "Nature of Religion The CognitiveDevelopmental Approach as the Grand Theory of Religion." Russian Journal of Sociology 4(1):10-27.

Pesurnay, Althien John. 2018. "Local Wisdom in a New Paradigm: Applying System Theory to the Study of Local Culture in Indonesia." IOP Conference Series: Earth and Environmental Science 175(1):1-8.

Saliem, Handewi Purwati dan Mewa Ariani. 2002. "Ketahanan Pangan: Konsep, Pengukuran dan Strategi." FAE 20(1):12-24.

Sari, Syafriani Tio. 2019. "Sinadong Local Wisdom Tanjungbalai Malay 
Oral Traditions Literary Anthropology Approach." L'Geneus: The Journal Language Generations of Intellectual Society Journal 8(1):913. 
